\title{
Dampak Profesionalisme, Integritas, Kompetensi, dan Independensi pada Kualitas Audit di Kantor Akuntan Publik Provinsi Bali
}

\author{
Ni Luh Rosa Aprilianti ${ }^{1}$ \\ Fakultas Ekonomi dan Bisnis \\ Universitas Udayana, Indonesia
}

\author{
I Dewa Nyoman Badera ${ }^{2}$ \\ Fakultas Ekonomi dan Bisnis \\ Universitas Udayana, Indonesia
}

\begin{abstract}
Surel : rosaaprilianti@gmail.com
ABSTRAK

Kualitas audit yang dihasilkan akuntan publik memang tengah mendapat sorotan dari masyarakat setelah terjadi beberapa skandal yang melibatkan akuntan publik baik dari luar maupun dari dalam negeri. Penelitian ini bertujuan untuk mengetahui pengaruh profesionalisme, integritas, kompetensi, dan independensi pada kualitas audit di Kantor Akuntan Publik Provinsi Bali. Penelitian ini dilakukan di KAP Provinsi Bali yang terdaftar di IAPI berjumlah 14 KAP. Sampel yang digunakan sebanyak 118 orang auditor, dengan metode sampling jenuh. Pengumpulan data dengan menyebarkan kuesioner dengan responden yang kembali berjumlah 73 orang. Teknik analisis yang digunakan adalah regresi linear berganda. Berdasarkan hasil analisis ditemukan bahwa profesionalisme, integritas, dan independensi berpengaruh positif pada kualitas audit di KAP Provinsi Bali. Sedangkan kompetensi tidak berpengaruh pada kualitas audit di KAP Provinsi Bali.
\end{abstract}

Kata Kunci: Profesionalisme; Integritas; Kompetensi; Independensi; Kualitas Audit.

\section{The Effect of Professionalism, Integrity, Competency, and Independence on Audit Quality in The Public Accountant Office of Bali Province}

\begin{abstract}
The quality of audits produced by public accountants is indeed under the spotlight of the public after several scandals involving public accountants, both from outside and from within the country. This study aims to determine the effect of professionalism, integrity, competence, and independence on audit quality at the Bali Province Public Accountant Office. This research was conducted in KAP Bali Province which is registered with IAPI totaling $16 \mathrm{KAP}$. The sample used was 118 auditors, with a saturated sampling method. Collecting data by distributing questionnaires with respondents who returned numbered 73 people. The analysis technique used is multiple linear regression. Based on the results of the analysis, it was found that professionalism, integrity, and independence had a positive effect on audit quality in KAP Bali Province. Meanwhile competence has no effect on audit quality in KAP Bali Province.
\end{abstract}

Keywords: Professionalism; Integrity; Competence; Independence; Audit Quality.

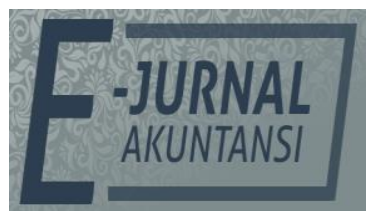

e-ISSN 2302-8556

Vol. 31 No. 2

Denpasar, Februari 2021 Hal. 463-475

DOI:

10.24843/EJA.2021.v31.i02.p16

PENGUTIPAN:

Aprilianti, N.L.R., \& Badera, I D.N. (2021). Dampak

Profesionalisme, Integritas, Kompetensi, dan Independensi pada Kualitas Audit di Kantor Akuntan Publik Provinsi Bali. E-Jurnal Akuntansi, 31(2), . 463-475

RIWAYAT ARTIKEL: Artikel Masuk: 9 November 2020 Artikel Diterima: 8 Februari 2021

Artikel dapat diakses : https://ojs.unud.ac.id/index.php/Akuntansi/index 


\section{PENDAHULUAN}

Pada perkembangan dunia usaha saat ini telah dijelaskan bahwa kebutuhan akan audit semakin meningkat. Hal ini dikarenakan informasi perusahaan semakin terbuka, dimana kepemilikan terhadap entitas usaha yang terdiri dari saham dan investasi dapat dimiliki oleh berbagai pihak. Pemilik dan pengelola (manajemen) yang terpisah mengharuskan laporan keuangan yang dibuat dan disajikan oleh manajemen kepada pemilik diperiksa kebenaran dan kewajaran sesuai dengan aturan dan ketentuan yang berlaku (Sarca \& Rasmini, 2019). Maka dari itu laporan keuangan harus teruji kebenarannya dan oleh sebab itu perlu diadakannya kegiatan pemeriksaan pihak yang independen yaitu oleh Akuntan Publik agar dapat membuat penilaian dan pandangan dari masyarakat semakin baik.

Isu terkait kualitas audit banyak diperbincangkan sejak terjadinya skandal Enron Corp. dan WorldCom Inc. Tindak manipulasi laporan keuangan ini didukung oleh KAP legendaris dunia, yakni KAP Andersen. Kasus skandal akuntansi yang menimpa akuntan publik sempat kembali terjadi belakangan ini. Kementerian Keuangan menyatakan dua akuntan publik yang mengaudit laporan keuangan PT Sunprima Nusantara Pembiayaan (SNP) Finance, yaitu Akuntan Publik Marlinna dan Merliyana Syamsul melanggar standar audit profesional. Selain itu, salah satu kasus yang sempat ramai diberitakan adalah kasus yang dialami oleh PT Garuda Indonesia (Persero) Tbk pada tahun 2018. Pembekuan izin Akuntan Publik juga sempat terjadi pada Kantor Akuntan Publik Provinsi Bali pada Mei 2007. KAP K. Gunarsa telah melakukan pelanggaran terhadap Standar Profesional Akuntan Publik (SPAP).

Kualitas audit yang dihasilkan akuntan publik memang tengah mendapat sorotan dari masyarakat setelah terjadi beberapa skandal yang melibatkan akuntan publik baik dari luar negeri maupun dari dalam negeri. Kualitas audit yang baik tentunya tidak terbentuk begitu saja. Ada beberapa faktor yang mempengaruhi, salah satunya yaitu profesionalisme. Profesionalisme merupakan suatu keharusan bagi seorang auditor dalam menjalankan tugasnya. Akan semakin penting apabila profesionalisme dihubungkan dengan hasil kerja individunya sehingga pada akhirnya dapat memberi keyakinan terhadap laporan keuangan bagi sebuah perusahaan. Auditor yang memiliki pandangan profesionalisme yang tinggi akan memberikan kontribusinya yang dapat dipercaya oleh para pengambil keputusan (Fietoria \& Manalu, 2016). Penelitian terdahulu yang dikemukakan oleh Trisna (2018) dan Lesmana \& Machdar (2015) menunjukkan bahwa profesionalisme berpengaruh positif terhadap kualitas audit. Hasil penelitian lainnya yang berbeda yaitu Fietoria \& Manalu (2016) dan Futri \& Juliarsa (2014) menunjukkan bahwa profesionalisme tidak berpengaruh positif terhadap kualitas audit. Sedangkan Susilo \& Widyastuti (2015) menunjukkan bahwa profesionalisme berpengaruh negatif terhadap kualitas audit.

Faktor lain yang dapat memberikan pengaruh pada kualitas audit adalah integritas. Integritas adalah suatu karakter seseorang untuk mewujudkan apa yang telah disanggupi dan diyakini kebenarannya. Integritas mengharuskan auditor untuk bersikap jujur, transparan, berani, bijaksana, dan bertanggung jawab dalam melaksanakan audit (Trisna, 2018). (Sukriyah et al., 2009) menyatakan bahwa integritas dapat menerima kesalahan yang tidak disengaja dan perbedaan pendapat yang jujur, tetapi tidak dapat menerima kecurangan prinsip. Dengan 
integritas yang tinggi, maka auditor dapat meningkatkan kualitas hasil pemeriksaannya. Penelitian terdahulu oleh Trisna (2018) dan (Haryadi, 2017) menyatakan bahwa integritas berpengaruh positif terhadap kualitas audit.

Selain profesionalisme dan integritas, kompetensi juga berpengaruh pada kualitas audit. Kompetensi adalah kemampuan untuk mengaplikasikan pengetahuan yang dimiliki dalam melakukan audit sehingga auditor dapat melakukan audit dengan teliti, cermat serta objektif. Seorang auditor yang berkompeten dapat dengan mudah, cepat, intuitif dan sangat jarang atau tidak pernah membuat kesalahan. Auditor yang berkompeten harus memiliki pengetahuan dan keterampilan prosedural yang luas. Penelitian terdahulu yang dikemukakan oleh Azizi \& Muliartha (2018), Gaol (2017), Fietoria \& Manalu (2016), Lesmana \& Machdar (2015), Dewi \& Budiartha (2015) menunjukkan bahwa kompetensi berpengaruh positif terhadap kualitas audit. Hasil penelitian lainnya yang berbeda yaitu Oklivia \& Marlinah (2014) menunjukkan bahwa kompetensi tidak berpengaruh positif terhadap kualitas audit.

Auditor juga perlu bersikap independen untuk mematangkan pertimbangan dalam menyusun laporan hasil pemeriksaan audit juga untuk mencapai harapan para klien yakni audit yang berkualitas. Menurut Mulyadi (2010) independensi dapat diartikan sebagai sikap mental yang bebas dari pengaruh pihak lain. Independensi juga berarti adanya sebuah tindak kejujuran dalam diri auditor untuk mempertimbangkan fakta yang objektif dan tidak memihak dalam diri auditor dalam merumuskan dan menyatakan pendapatnya. Semakin auditor mempertahankan independensinya semakin baik pula kualitas audit yang dihasilkan karena auditor yang independen dapat memberikan pendapat yang lebih tepat dibanding auditor yang tidak independen. Penelitian terdahulu yang dikemukakan oleh Sarca \& Rasmini (2019), Wulandari \& Wirakusuma (2017), Lesmana \& Machdar (2015) menunjukkan bahwa independensi berpengaruh positif terhadap kualitas audit. Hasil penelitian lainnya yang berbeda yaitu Sumito \& Setiyawati (2019), Fietoria \& Manalu (2016), Oklivia \& Marlinah (2014) dan Futri \& Juliarsa (2014) menunjukkan bahwa independensi tidak berpengaruh positif terhadap kualitas audit.

Penelitian ini menggunakan Teori Keagenan serta Teori Sikap dan Perilaku sebagai grand theory. Teori keagenan dalam audit berkaitan dengan auditor sebagai pihak ketiga yang akan membantu untuk mengatasi konflik kepentingan yang dapat muncul antara manajemen dan pemilik perusahaan. Jasa auditor diperlukan untuk menguji apakah laporan keuangan yang telah dibuat sudah disajikan secara wajar dan dapat dipercaya. Teori sikap dan perilaku mampu mempengaruhi auditor dalam mengelola faktor personalnya sehingga mampu bertindak jujur, tidak memihak pada suatu kepentingan tertentu, berpikir rasional, dan senantiasa berperilaku etis.

Profesionalisme merupakan suatu sikap yang dimiliki oleh seseorang yang melaksanakan pekerjaan sesuai dengan keahlian dalam bidangnya masing-masing dan mampu meminimalisir kesalahan dalam mengaudit laporan keuangan. Profesionalisme auditor berkaitan dengan teori keagenan, dimana seseorang dalam melakukan audit harus memberikan informasi atau opini yang rinci dan relevan kepada agen. Profesionalisme jika dikaitkan dengan teori sikap dan perilaku menitikberatkan pada cerminan tingkah laku seseorang dalam hal ini 
adalah auditor dalam bertindak dan berperilaku sesuai dengan etika. Semakin tinggi auditor dengan pandangan profesionalisme yang tinggi akan memberikan pengaruh yang baik bagi kinerjanya, sehingga hasil audit laporan keuangan akan lebih dapat dipercaya oleh para pengambil keputusan. Penelitian tersebut didukung oleh penelitan Lesmana \& Machdar (2015), Suardinatha \& Wirakusuma (2016), Trisna (2018) serta Purwaningsih \& Suputra (2018) memiliki hasil yang sama yaitu profesionalisme auditor berpengaruh positif terhadap kualitas audit. Berdasarkan uraian dan hasil-hasil penelitian tersebut, maka rumusan hipotesis dalam penelitian ini sebagai berikut.

$\mathrm{H}_{1}$ : Profesionalisme berpengaruh positif pada kualitas audit di Kantor Akuntan Publik Provinsi Bali.

Integritas merupakan kualitas yang mendasari kepercayaan publik dan merupakan patokan bagi anggota dalam menguji semua keputusan yang diambil. Teori sikap dan perilaku mampu mempengaruhi auditor dalam mengelola faktor personalnya sehingga mampu untuk bersikap jujur, transparan, berani, bijaksana dan bertanggungjawab dalam melaksanakan audit. Auditor yang memiliki integritas yang tinggi, maka akan dapat meningkatkan kualitas hasil pemeriksaannya. Penelitian yang dilakukan oleh Haryadi (2017), Gaol (2017) serta Trisna (2018) menyatakan bahwa integritas berpengaruh positif terhadap kualitas audit. Berdasarkan uraian dan hasil-hasil penelitian tersebut, maka rumusan hipotesis dalam penelitian ini adalah sebagai berikut.

$\mathrm{H}_{2}$ : Integritas berpengaruh positif pada kualitas audit di Kantor Akuntan Publik

Provinsi Bali

Kompetensi merupakan kemampuan untuk mengaplikasikan pengetahuan yang dimiliki dalam melakukan audit. Kompetensi yang dibutuhkan dalam melakukan audit yaitu pengetahuan dan kemampuan. Auditor harus memiliki pengetahuan untuk memahami entitas yang diaudit dan juga kemampuan untuk bekerja sama dalam tim serta dapat menganalisa permasalahan. Kompetensi berkaitan dengan teori keagenan, dimana auditor digunakan untuk meyakinkan prinsipal bahwa agen telah bekerja secara maksimal. Untuk menghasilkan kualitas audit yang baik maka diperlukan auditor yang berkompeten sehingga dapat memberikan pendapat wajar pada laporan keuangan. Semakin tinggi kompetensi seorang auditor, maka kualitas audit yang dihasilkan oleh auditor akan semakin akurat. Penelitian terdahulu yang dikemukakan oleh Sumito \& Setiyawati (2019) menyatakan kompetensi auditor berpengaruh signifikan pada kualitas audit dan arahnya positif. Begitu juga penelitian yang dilakukan oleh Azizi \& Muliartha (2018), Gaol (2017), Fietoria \& Manalu (2016), Lesmana \& Machdar (2015), Dewi \& Budiartha (2015) menunjukkan bahwa kompetensi berpengaruh positif terhadap kualitas audit. Berdasarkan uraian dan hasil-hasil penelitian tersebut, maka rumusan hipotesis dalam penelitian ini adalah sebagai berikut.

$\mathrm{H}_{3}$ : Kompetensi berpengaruh positif pada kualitas audit di Kantor Akuntan Publik

Provinsi Bali.

Independensi merupakan sikap mental yang bebas dari pengaruh, tidak dikendalikan oleh pihak lain, tidak tergantung pada orang lain. Independensi jika dikaitkan dengan teori keagenan, dimana auditor sebagai pihak ketiga yang independen sangat dibutuhkan sebagai mediator untuk menjembatani antara agent dan principal. Teori sikap dan perilaku mampu mempengaruhi auditor dalam 
mengelola faktor personalnya dimana salah satunya yaitu independensi sehingga mampu memberikan kejujuran dalam diri auditor dalam mempertimbangkan fakta dan adanya pertimbangan yang objektif tidak memihak dalam diri auditor dalam menyatakan pendapatanya. Semakin tinggi independensi seorang auditor, maka auditor akan memiliki kemampuan untuk memahami konflik kepentingan yang dapat muncul antara pemilik perusahaan dan pengelola perusahaan. Penelitian yang dilakukan oleh Sarca \& Rasmini (2019) dan Wulandari \& Wirakusuma (2017) menyatakan bahwa independensi memiliki pengaruh positif pada kualitas audit. Berdasarkan uraian dan hasil-hasil penelitian tersebut, maka rumusan hipotesis dalam penelitian ini adalah sebagai berikut.

$\mathrm{H}_{4}$ : Independensi berpengaruh positif pada kualitas audit di Kantor Akuntan Publik Provinsi Bali.

\section{METODE PENELITIAN}

Variabel-variabel yang digunakan dalam penelitian ini dapat diidentifikasi sebagai berikut: 1) Variabel terikat dalam penelitian ini adalah kualitas Audit (Y), 2) Variabel bebas pada penelitian ini yaitu: Profesionalisme $\left(X_{1}\right)$, Integritas $\left(X_{2}\right)$, Kompetensi $\left(\mathrm{X}_{3}\right)$, Independensi $\left(\mathrm{X}_{4}\right)$. Jenis data yang digunakan pada penelitian ini adalah data kuantitatif dan data kualitatif.

Populasi penelitian ini adalah seluruh auditor yang bekerja pada Kantor Akuntan Publik di Provinsi Bali, sejumlah 118 orang pada 14 Kantor Akuntan Publik. Teknik penentuan sampel dalam penelitian ini adalah teknik sampling jenuh sehingga sampel berjumlah 118 auditor.

Tabel 1. Jumlah Auditor pada Kantor Akuntansi Publik di Provinsi Bali

\begin{tabular}{clc}
\hline No & \multicolumn{1}{c}{ Nama KAP } & Jumlah Auditor \\
\hline 1. & KAP Amachi, Arifin, Mardani \& Muliadi (Cabang) & 3 \\
2. & KAP Arimbawa & 4 \\
3. & KAP Arnaya \& Darmayasa & 2 \\
4. & KAP Artayasa & 4 \\
5. & KAP Budhananda Munidewi & 7 \\
6. & KAP I Gede Bandar Wira Putra & 6 \\
7. & KAP I Gede Oka & 7 \\
8. & KAP. I Wayan Ramantha & 8 \\
9. & KAP Johan Malonda Mustika dan Rekan (Cabang) & 15 \\
10. & KAP. K. Gunarsa & 24 \\
11. & KAP Ketut Budhiartha dan Anggiriawan & 14 \\
12. & KAP Ketut Muliartha RM & 7 \\
13. & KAP Drs. Sri Marmo Djogosarkoro & 12 \\
14. & KAP Tjahjo, Machdjud Modopuro \& Rekan (Cabang) & 5 \\
& Total & 118 \\
\hline
\end{tabular}

Sumber: Data Penelitian, 2020

Metode pengumpulan data pada penelitian ini menggunakan metode survei dengan teknik pengumpulan data menggunakan angket (kuesioner). Dalam penelitian ini pernyataan yang disebarkan mengenai profesionalisme, integritas, kompetensi, independensi dan kualitas audit. Peneliti menggunakan skala likert 5 poin. Skala likert ini memudahkan responden untuk menjawab kuesioner apakah setuju atau tidak setuju dan mudah dipahami oleh responden. Peneliti menggunakan skala likert 5 poin dengan alasaan dapat memberikan responden 
pilihan yang lebih banyak dan dapat meningkatkan diferensiasi poin.

Teknik analisis data yang digunakan yaitu analisis regresi linear berganda. Analisis regresi linear berganda merupakan teknik statistik melalui koefisien parameter untuk mengetahui besarnya pengaruh variabel independen terhadap variabel dependen. Model persamaan regresi yang digunakan dalam penelitian ini diasumsikan linear dan diuji dengan tingkat signifikansi $a=0,05$ (Sugiyono, 2018:305). Adapun model persamaan analisis regresi penelitian ini adalah sebagai berikut.

$$
Y=\alpha+\beta_{1} X_{1}+\beta_{2} X_{2}+\beta_{3} X_{3}+\beta_{4} X_{4}+\varepsilon
$$

Keterangan:

$\mathrm{Y}=$ Kualitas Audit

$\alpha=$ Konstanta

$\beta_{1}, \beta_{2}, \beta_{3,} \beta_{4}=$ koefisien regresi

$\mathrm{X}_{1}=$ Variabel independen, yaitu profesionalisme

$\mathrm{X}_{2}=$ Variabel independen, yaitu integritas

$\mathrm{X}_{3}=$ Variabel independen, yaitu kompetensi

$\mathrm{X}_{4}=$ Variabel independen, yaitu independensi

$\varepsilon=$ Standard Error

\section{HASIL DAN PEMBAHASAN}

Total auditor pada seluruh KAP yaitu 118 tetapi kuesioner yang kembali hanya berjumlah 73 responden. Hal ini dikarenakan pembatasan penyebaran kuesioner pada setiap KAP. Kuesioner layak dianalisis dengan tingkat pengembalian sebesar $61,9 \%$. Hasil statistik deskriptif dari masing - masing variabel disajikan pada Tabel 2.

Tabel 2. Hasil Uji Statistik Deskriptif

\begin{tabular}{llllll}
\hline Variabel & $\mathrm{N}$ & Min. & Max. & Mean & Std. Deviation \\
\hline Profesionalisme $\left(\mathrm{X}_{1}\right)$ & 73 & 17 & 25 & 19,82 & 1,494 \\
Integritas $\left(\mathrm{X}_{2}\right)$ & 73 & 17 & 25 & 20,48 & 1,749 \\
Kompetensi $\left(\mathrm{X}_{3}\right)$ & 73 & 18 & 25 & 20,95 & 1,508 \\
Independensi $\left(\mathrm{X}_{4}\right)$ & 73 & 16 & 25 & 19,37 & 1,860 \\
Kualitas Audit $(\mathrm{Y})$ & 73 & 19 & 30 & 23,74 & 1,900 \\
\hline
\end{tabular}

Sumber: Data Penelitian, 2020

Berdasarkan Tabel 2, dapat dijelaskankan hal-hal sebagai berikut. Jumlah pengamatan $(\mathrm{N})$ penelitian ini berjumlah 73 . Profesionalisme $\left(X_{1}\right)$ yang diukur dengan 5 item pernyataan memiliki nilai minimum sebesar 17 , nilai maksimum sebesar 25 dan nilai rata-rata sebesar 19,82 yang berarti kecenderungan responden memiliki tingkat profesionalisme yang rendah. Nilai standar deviasi variabel profesionalisme sebesar 1,494. Hal ini berarti standar penyimpangan data terhadap nilai rata-ratanya adalah 1,494.

Integritas $\left(\mathrm{X}_{2}\right)$ yang diukur dengan 5 item pernyataan memiliki nilai minimum sebesar 17, nilai maksimum sebesar 25 dan nilai rata-rata sebesar 20,48 yang berarti kecenderungan responden memiliki tingkat integritas yang cukup. Nilai standar deviasi variabel integritas sebesar 1,749. Hal ini berarti standar penyimpangan data terhadap nilai rata-ratanya adalah 1,749.

Kompetensi $\left(X_{3}\right)$ yang diukur dengan 5 item pernyataan memiliki nilai minimum sebesar 18, nilai maksimum sebesar 25 dan nilai rata-rata sebesar 20,95 
yang berarti kecenderungan responden memiliki tingkat kompetensi yang cukup. Nilai standar deviasi kompetensi sebesar 1,508. Hal ini berarti standar penyimpangan data terhadap nilai rata-ratanya adalah 1,508 .

Independensi $\left(\mathrm{X}_{4}\right)$ yang diukur dengan 5 item pernyataan memiliki nilai minimum sebesar 16, nilai maksimum sebesar 25 dan nilai rata-rata sebesar 19,37 yang berarti kecenderungan responden memiliki tingkat independensi yang cukup. Nilai standar deviasi independensi sebesar 1,860. Hal ini berarti standar penyimpangan data terhadap nilai rata-ratanya adalah 1,860 .

Kualitas audit $(\mathrm{Y})$ yang diukur dengan 6 item pernyataan memiliki nilai minimum sebesar 19, nilai maksimum sebesar 30 dan nilai rata-rata sebesar 23,74 yang berarti kecenderungan responden untuk menghasilkan kualitas audit adalah cukup. Nilai standar deviasi kualitas audit sebesar 1,900. Hal ini berarti standar penyimpangan data terhadap nilai rata-ratanya adalah 1,900.

Tabel 3. Hasil Uji Normalitas

\begin{tabular}{ll}
\hline & Unstandardized Residual \\
\hline $\mathrm{N}$ & 73 \\
Kolmogorov-Smirnov & 1,340 \\
Asymp.sig (2-tailed) & 0,055 \\
\hline
\end{tabular}

Sumber: Data Penelitian, 2020

Berdasarkan Tabel 3, hasil uji normalitas menunjukkan nilai signifikan Asymp. Sig. (2-tailed) sebesar 0,055 > 0,050. Dapat disimpulkan bahwa data yang digunakan dalam penelitian ini adalah data yang berdistribusi normal.

Tabel 4. Hasil Uji Multikolinearitas

\begin{tabular}{lll}
\hline Variabel & Tolerance & VIF \\
\hline Profesionalisme $\left(\mathrm{X}_{1}\right)$ & 0,409 & 2,445 \\
Integritas $\left(\mathrm{X}_{2}\right)$ & 0,486 & 2,057 \\
Kompetensi $\left(\mathrm{X}_{3}\right)$ & 0,960 & 1,041 \\
Independensi $\left(\mathrm{X}_{4}\right)$ & 0,464 & 2,155 \\
\hline
\end{tabular}

Sumber: Data Penelitian, 2020

Berdasarkan Tabel 4, diketahui bahwa nilai Tolerance dari masing-masing variabel lebih besar dari 0,10. Sementara itu, nilai VIF dari masing-masing variabel lebih kecil dari 10,00. Sehingga dapat dinyatakan bahwa dalam regresi tersebut tidak terjadi multikolinearitas.

Tabel 5. Hasil Uji Heteroskedastisitas

\begin{tabular}{lll}
\hline Variabel & Sig. & Keterangan \\
\hline Profesionalisme & 0,549 & Bebas Heteroskedastisitas \\
Integritas & 0,711 & Bebas Heteroskedastisitas \\
Kompetensi & 0,895 & Bebas Heteroskedastisitas \\
Independensi & 0,067 & Bebas Heteroskedastisitas \\
\hline
\end{tabular}

Sumber: Data Penelitian, 2020

Berdasarkan Tabel 5, hasil uji heteroskedastisitas menunjukkan bahwa keseluruhan variabel memiliki nilai signifikansi melebihi 0,05 sehingga data penelitian dapat disimpulkan terbebas dari heteroskedastisitas.

Tabel 6, menyatakan Nilai konstanta sebesar 0,068 menunjukkan bahwa jika variabel profesionalisme, integritas, kompetensi dan independensi sama dengan nol, maka cenderung tidak terdapat kualitas audit.

Nilai koefisien $\beta_{1}$ pada profesionalisme $\left(X_{1}\right)$ sebesar 0,378 mempunyai hubungan positif pada kualitas audit. Ini menunjukkan bahwa jika 
profesionalisme $\left(\mathrm{X}_{1}\right)$ meningkat, maka akan terjadi peningkatan kualitas audit $(\mathrm{Y})$ dengan asumsi variabel bebas lainnya dianggap konstan.

Nilai koefisien $\beta_{2}$ pada integritas $\left(X_{2}\right)$ sebesar 0,361 mempunyai hubungan positif pada kualitas audit. Ini menunjukkan bahwa jika integritas $\left(\mathrm{X}_{2}\right)$ meningkat, maka akan terjadi peningkatan kualitas audit (Y) dengan asumsi variabel bebas lainnya dianggap konstan.

Nilai koefisien $\beta_{3}$ pada kompetensi $\left(X_{3}\right)$ sebesar 0,075 mempunyai hubungan positif pada kualitas audit. Ini menunjukkan bahwa jika kompetensi $\left(X_{3}\right)$ meningkat, maka cenderung tidak terjadi peningkatan kualitas audit (Y) dengan asumsi variabel bebas lainnya dianggap konstan.

Nilai koefisien $\beta_{4}$ pada independensi $\left(X_{4}\right)$ sebesar 0,372 mempunyai hubungan positif pada kualitas audit. Ini menunjukkan bahwa jika independensi $\left(\mathrm{X}_{4}\right)$ meningkat, maka akan terjadi peningkatan kualitas audit $(\mathrm{Y})$ dengan asumsi variabel bebas lainnya dianggap konstan.

Tabel 6. Hasil Analisis Regresi Linear Berganda

\begin{tabular}{|c|c|c|c|c|c|c|}
\hline \multirow{2}{*}{\multicolumn{2}{|c|}{ Model }} & \multicolumn{2}{|c|}{$\begin{array}{l}\text { Unstandardized } \\
\text { Coefficients }\end{array}$} & \multirow{2}{*}{$\begin{array}{l}\text { Standardized } \\
\text { Coefficients } \\
\text { Beta } \\
\end{array}$} & \multirow[b]{2}{*}{$\mathrm{T}$} & \multirow[b]{2}{*}{ Sig. } \\
\hline & & $\mathrm{B}$ & Std. Error & & & \\
\hline \multirow[t]{5}{*}{1} & (Constant) & 0,068 & 2,309 & & 0,030 & 0,977 \\
\hline & Profesionalisme & 0,378 & 0,118 & 0,297 & 3,215 & 0,002 \\
\hline & Integritas & 0,361 & 0,092 & 0,333 & 3,926 & 0,000 \\
\hline & Kompetensi & 0,075 & 0,076 & 0,060 & 0,993 & 0,324 \\
\hline & Independensi & 0,372 & 0,089 & 0,364 & 4,195 & 0,000 \\
\hline
\end{tabular}

Sumber: Data Penelitian, 2020

Berdasarkan Tabel 6, dapat dibuat persamaan sebagai berikut.

$$
Y=0,068+0,378 X_{1}+0,361 X_{2}+0,075 X_{3}+0,372 X_{4}+\varepsilon
$$

Berdasarkan Tabel 7, tingkat signifikan yang digunakan adalah 0,05 . Nilai signifikan $\mathrm{F}$ atau $p$-value sebesar 0,000 yang menunjukkan bahwa nilai tersebut lebih kecil dari 0,05. Hal ini menunjukkan bahwa model mampu memrediksi fenomena penelitian.

Tabel 7. Hasil Uji Kelayakan Model (Uji F)

\begin{tabular}{|c|c|c|c|c|c|}
\hline Model & Sum of Squares & $D f$ & Mean Square & $F$ & Sig. \\
\hline 1 Regression & 198,360 & 4 & 49,590 & 54,658 & $0,000^{\mathrm{b}}$ \\
\hline Residual & 61,695 & 68 & 0,907 & & \\
\hline Total & 260,055 & 72 & & & \\
\hline
\end{tabular}

Sumber: Data Penelitian, 2020

Berdasarkan Tabel 8, dapat dilihat bahwa Adjusted $R$ Square sebesar 0,749 memiliki arti bahwa $74,9 \%$ kualitas audit dipengaruhi oleh profesionalisme, integritas, kompetensi dan independensi. Sisanya 25,1 \% dipengaruhi oleh variabel lain yang tidak masuk dalam model.

Tabel 8. Hasil Uji Koefisien Determinasi $\left(\mathbf{R}^{2}\right)$

\begin{tabular}{lllll}
\hline Model & $R$ & $R$ Square & Adjusted $R$ Square & $\begin{array}{l}\text { Std. Error of the } \\
\text { Estimate }\end{array}$ \\
\hline 1 & $0,873^{\mathrm{a}}$ & 0,763 & 0,749 & 0,953 \\
\hline
\end{tabular}

Sumber: Data Penelitian, 2020

Hipotesis pertama $\left(\mathrm{H}_{1}\right)$ menyatakan bahwa profesionalisme berpengaruh positif pada kualitas audit di Kantor Akuntan Publik Provinsi Bali. Setelah dilakukan pengujian, hasil pengujian menunjukkan bahwa nilai koefisien regresi 
variabel profesionalisme sebesar 0,378 . Nilai signifikansi profesionalisme sebesar $0,002<0,05$ yang berarti nilai t bersifat signifikan sehingga $\mathrm{H}_{1}$ yang menyatakan profesionalisme berpengaruh positif pada kualitas audit dapat diterima. Hasil penelitian mendukung teori utama yaitu teori keagenan dan teori sikap dan perilaku. Untuk meningatkan kualitas audit, seorang auditor dituntut agar bertindak profesional dalam melakukan pemeriksaan. Auditor dengan pandangan profesionalisme yang tinggi akan memberikan pengaruh yang baik bagi kinerjanya, sehingga hasil audit laporan keuangan akan lebih dapat dipercaya oleh para pengambil keputusan. Hasil penelitian ini didukung oleh penelitan Lesmana \& Machdar (2015), Suardinatha \& Wirakusuma (2016), Trisna (2018) serta Purwaningsih \& Suputra (2018) menyatakan bahwa profesionalisme auditor berpengaruh positif pada kualitas audit.

Tabel 9. Uji Hipotesis (Uji t)

\begin{tabular}{|c|c|c|c|c|c|c|}
\hline \multirow{2}{*}{\multicolumn{2}{|c|}{ Model }} & \multicolumn{2}{|c|}{ Unstandardized Coefficients } & \multirow{2}{*}{$\begin{array}{l}\text { Standardized } \\
\text { Coefficients } \\
\text { Beta }\end{array}$} & \multirow[b]{2}{*}{$\mathrm{T}$} & \multirow[b]{2}{*}{ Sig. } \\
\hline & & B & Std. Error & & & \\
\hline \multirow[t]{5}{*}{1} & (Constant) & 0,068 & 2,309 & & 0,030 & 0,977 \\
\hline & Profesionalisme & 0,378 & 0,118 & 0,297 & 3,215 & 0,002 \\
\hline & Integritas & 0,361 & 0,092 & 0,333 & 3,926 & 0,000 \\
\hline & Kompetensi & 0,075 & 0,076 & 0,060 & 0,993 & 0,324 \\
\hline & Independensi & 0,372 & 0,089 & 0,364 & 4,195 & 0,000 \\
\hline
\end{tabular}

Sumber: Data Penelitian, 2020

Hipotesis kedua $\left(\mathrm{H}_{2}\right)$ menyatakan bahwa integritas berpengaruh positif pada kualitas audit di Kantor Akuntan Publik Provinsi Bali. Setelah dilakukan pengujian, hasil pengujian menunjukkan bahwa nilai koefisien regresi variabel integritas sebesar 0,361. Nilai signifikansi integritas sebesar 0,000 $<0,05$ yang berarti nilai $t$ bersifat signifikan sehingga $\mathrm{H}_{2}$ yang menyatakan integritas berpengaruh positif pada kualitas audit dapat diterima. Penelitian ini mendukung teori utama yaitu teori sikap dan perilaku. Teori ini mampu mempengaruhi auditor dalam mengelola faktor personalnya sehingga mampu untuk bersikap jujur, transparan, berani, bijaksana dan bertanggungjawab dalam melaksanakan audit. Hal ini menunjukkan bahwa auditor yang memiliki integritas yang tinggi akan dapat meningkatkan kualitas hasil pemeriksaannya. Integritas merupakan kualitas yang menjadikan timbulnya kepercayaan masyarakat dan merupakan tatanan nilai tertinggi bagi auditor untuk mengambil keputusan. Hasil penelitian ini didukung dengan penelitian yang dilakukan oleh Haryadi (2017) yang menyatakan bahwa integritas berpengaruh terhadap kualitas audit. Begitu juga penelitian Gaol (2017) serta Trisna (2018) menyatakan bahwa integritas berpengaruh positif terhadap kualitas audit.

Hipotesis ketiga $\left(\mathrm{H}_{3}\right)$ menyatakan bahwa kompetensi berpengaruh positif pada kualitas audit di Kantor Akuntan Publik Provinsi Bali. Setelah dilakukan pengujian, hasil pengujian menunjukkan bahwa nilai koefisien regresi variabel kompetensi sebesar 0,075. Nilai signifikansi kompetensi sebesar 0,324 >0,05 yang berarti nilai $\mathrm{t}$ bersifat tidak signifikan sehingga $\mathrm{H}_{3}$ yang menyatakan kompetensi berpengaruh positif pada kualitas audit tidak dapat diterima. Hasil penelitian tidak mendukung teori utama namun mendukung hasil penelitian yang dilakukan oleh Oklivia \& Marlinah (2014), Ningsih \& Sofianti (2015), Dewi \& Budiartha 
(2015), dan Maharany et al., (2016) yang menyatakan bahwa tingginya kompetensi yang dimiliki oleh auditor tidak menjamin peningkatan kualitas audit yang dihasilkan. Penelitian yang dilakukan Ningsih \& Sofianti (2015) memproksikan variabel kompetensi dalam dua hal yaitu pengetahuan dan pengalaman yang tidak selamanya berpengaruh terhadap kualitas audit. Pengalaman auditor tidak banyak memberikan kontribusi untuk meningkatkan kompetensi auditor dan tidak juga berpengaruh terhadap kualitas audit. Seringkali pengetahuan auditor yang dianggap dapat meningkatkan kompetensi auditor ini juga dilihat dari latar belakang pendidikan formal akuntansi. Namun tampaknya kurikulum pendidikan formal akuntansi dirasakan tidak lagi dapat mengejar perkembangan isu-isu terbaru yang ada di dunia praktek sehingga para lulusannya bisa saja dianggap memiliki kompetensi yang baik dari segi pendidikan dan pengetahuannya namun belum tentu mencerminkan kemampuan sesungguhnya saat berhadapan dengan kasus-kasus yang lebih kompleks di dunia praktek. Berdasarkan penelitian Dewi \& Budiartha (2015) Faktor yang menjadi penyebab kompetensi tidak berpengaruh pada kualitas audit adalah responden sebagian besar adalah auditor junior. Dalam sebuah tim audit, auditor yang berkedudukan sebagai auditor junior mendapatkan pengawasan dari jenjang auditor di atasnya. Hal ini dilakukan untuk menghindari kesalahan selama proses audit. Jadi, perlu adanya review hasil audit yang dikerjakan oleh auditor jenjang junior. Pada penelitian ini faktor yang menjadi penyebab kompetensi tidak berpengaruh pada kualitas audit salah satunya adalah responden sebanyak $82,2 \%$ memiliki latar belakang pendidikan akhir Strata-1. Selama menempuh pendidikan S1, pemberian materi auditing hanya diberikan secara teori sehingga dalam praktik akan mengalami kesulitan. Maka dari itu auditor wajib menempuh Pendidikan Profesi Berkelanjutan (Continuing Professional Education) untuk meningkatkan kemampuan dalam bidang auditing. Hal ini didukung dengan pengalaman auditor sebanyak 30,1\% berpengalaman selama $<2$ tahun dan $56,2 \%$ berpengalaman selama 2-5 tahun. Dilihat dari jumlah tahun pengalaman yang dimiliki auditor dengan rentang waktu tersebut, auditor memiliki kemampuan yang kurang memadai dalam menganalisa dan mengidentifikasi temuan-temuan audit selama proses audit. Kurangnya pengalaman yang dimiliki akan menyebabkan tindakan dalam pengambilan keputusan tidak maksimal.

Hipotesis keempat $\left(\mathrm{H}_{4}\right)$ menyatakan bahwa independensi berpengaruh positif pada kualitas audit di Kantor Akuntan Publik Provinsi Bali. Setelah dilakukan pengujian, hasil pengujian menunjukkan bahwa nilai koefisien regresi variabel independensi sebesar 0,372. Nilai signifikansi independensi sebesar 0,000 $<0,05$ yang berarti nilai $\mathrm{t}$ bersifat signifikan sehingga $\mathrm{H}_{4}$ yang menyatakan independensi berpengaruh positif pada kualitas audit dapat diterima. Penelitian ini mendukung teori utama yaitu teori keagenan dan teori sikap dan perilaku. Hal ini menunjukkan semakin auditor meningkatkan independensinya, maka akan semakin mampu dalam mempertimbangkan fakta dan adanya pertimbangan yang objektif tidak memihak dalam diri auditor dalam menyatakan pendapatanya. Semakin tinggi independensi seorang auditor, maka auditor akan memiliki kemampuan untuk memahami konflik kepentingan yang dapat muncul antara pemilik perusahaan dan pengelola perusahaan. Penelitian ini didukung oleh penelitian yang dilakukan oleh Sarca \& Rasmini (2019) dan Wulandari \& 
Wirakusuma (2017) menyatakan bahwa independensi memiliki pengaruh positif pada kualitas audit.

\section{SIMPULAN}

Berdasarkan hasil dan pembahasan yang sudah dijelaskan sebelumnya, maka dapat disimpulkan sebagai berikut. Profesionalisme berpengaruh positif pada kualitas audit di Kantor Akuntan Publik Provinsi Bali. Hal ini menunjukkan bahwa auditor yang memiliki profesionalisme yang tinggi akan mengakibatkan kualitas audit yang dihasilkan semakin baik. Integritas berpengaruh positif pada kualitas audit di Kantor Akuntan Publik Provinsi Bali. Hal ini menunjukkan bahwa auditor yang memiliki tingkat integritas yang tinggi akan menghasilkan kualitas audit yang semakin baik. Kompetensi tidak berpengaruh pada kualitas audit di Kantor Akuntan Publik Provinsi Bali. Hal ini dikarenakan sebanyak 82,2\% responden memiliki latar belakang pendidikan S1, dimana selama menempuh pendidikan S1 pemberian auditing hanya diberikan secara teori sehingga dalam praktik akan mengalami kesulitan. Hal ini didukung dengan pengalaman auditor sebanyak $30,1 \%$ berpengalaman selama $<2$ tahun dan $56,2 \%$ berpengalaman selama 2-5 tahun. Dilihat dari pengalaman yang dimiliki auditor dengan rentang waktu tersebut, auditor memiliki kemampuan yang kurang memadai dalam menganalisa dan mengidentifikasi temuan-temuan audit selama proses audit. Kurangnya pengalaman yang dimiliki akan menyebabkan tindakan dalam pengambilan keputusan tidak maksimal. Independensi berpengaruh positif pada kualitas audit di Kantor Akuntan Publik Provinsi Bali. Hal ini menunjukkan semakin auditor mempertahankan independensinya semakin baik pula kualitas audit yang dihasilkan.

Berdasarkan hasil kuesioner variabel profesionalisme, pernyataan dengan rata-rata jawaban terendah adalah "Saya akan tetap teguh pada profesi sebagai auditor meskipun saya mendapat tawaran pekerjaan lain dengan imbalan yang lebih besar", sehingga peneliti menyarankan agar auditor harus tetap berpegang teguh pada profesinya karena auditor yang mengabdi kepada profesinya akan melakukan totalitas kerja dimana dengan totalitas ini auditor akan lebih hati-hati dalam melakukan audit dan bijaksana dalam mengambil keputusan. Berdasarkan hasil kuesioner variabel integritas, pernyataan dengan rata-rata jawaban terendah adalah "Saya tidak mempertimbangkan keadaan seseorang/sekelompok orang atau suatu unit organisasi untuk membenarkan perbuatan melanggar ketentuan atau peraturan perundang-undangan yang berlaku", sehingga peneliti menyarankan agar auditor harus mampu bersikap jujur dengan taat pada peraturan, tidak menambah atau mengurangi fakta dan tidak menerima segala sesuatu dalam bentuk apapun. Berdasarkan hasil kuesioner variabel kompetensi, pernyataan dengan rata-rata jawaban terendah adalah "Saya harus menyadari bahwa beberapa temuan bersifat subjektif", sehingga peneliti menyarankan agar auditor lebih meningkatkan mutu personal dimana salah satunya yaitu menyadari bahwa beberapa temuan bersifat subjektif. Auditor yang memiliki mutu personal yang baik akan mampu untuk memahami dan mengetahui berbagai masalah secara lebih mendalam dan lebih mudah dalam mengikuti perkembangan yang semakin kompleks dalam lingkungan audit kliennya.

Berdasarkan hasil kuesioner variabel independensi, pernyataan dengan rata- 
rata jawaban terendah adalah "Saya tidak memerlukan telaah dari rekan auditor untuk menilai prosedur audit karena kurang dirasa manfaatnya", sehingga peneliti menyarankan agar auditor memerlukan telaah dari rekan auditornya karena hal ini dilakukan untuk memonitor auditor agar dapat meningkatkan kualitas audit. Hasil Adjusted R Square sebesar 74,9\% menunjukkan bahwa masih ada variabel lain sebesar $25,1 \%$ yang dapat memengaruhi kualitas audit sehingga peneliti selanjutnya disarankan agar menambahkan variabel lain yang dapat memengaruhi kualitas audit seperti pengalaman auditor, locus of control dan audit tenure. Penggunakan sampel jenuh mengakibatkan penggunaan auditor yang berpengalaman $<2$ tahun untuk mengukur kompetensi menjadi kurang tepat, sehingga peneliti selanjutnya disarankan agar menggunakan metode purposive sampling. Untuk mengetahui konsistensi penelitian diharapkan peneliti berikutnya melakukan penelitian pada populasi yang berbeda serta disarankan agar memperluas ruang lingkup sampel tidak hanya auditor yang bekerja di KAP namun juga auditor yang bekerja di Badan Pemeriksaan Keuangan (BPK), sehingga hasil penelitian lebih mungkin untuk disimpulkan secara umum.

\section{REFERENSI}

Azizi, A. F., \& Muliartha, I. K. (2018). Analisis Perencanaan Audit dan Kompetensi Auditor pada Kualitas Audit di Perwakilan BPKP Provinsi Bali. E-Jurnal Akuntansi, 25, 851. https://doi.org/10.24843/eja.2018.v25.i02.p02

Dewi, D. A. C., \& I Ketut Budiartha. (2015). Pengaruh Kompetensi dan Independensi Auditor pada Kualitas Audit Dimoderasi oleh Tekanan Klien. E-Jurnal Akuntansi Universitas Udayana, 11(1), 197-210.

Fietoria, \& Manalu, E. S. (2016). Pengaruh Profesionalisme, Independensi, Kompetensi dan Pengalaman Kerja Terhadap Kualitas Audit di Kantor Akuntan Publik Bandung. Journal of Accounting and Business Studies, 1(1), 2038.

Futri, S., \& Juliarsa, G. (2014). Pengaruh Independensi, Profesionalisme, Tingkat Pendidikan, Etika Profesi, Pengalaman, dan Kepuasan Kerja Auditor terhadap Kualitas Audit pada Kantor Akuntan Publik di Bali. E-Jurnal Akuntansi 7(2): 444-461.

Gaol, R. L. (2017). Pengaruh Kompetensi, Independensi Dan Integritas Auditor Terhadap Kualitas Audit. Jrak, 3(1), 47-70.

Haryadi, T. (2017). Pengaruh Kompetensi, Independensi, Integritas, Pengalaman Kerja, dan Etika Auditor, dan Etika Auditor Terhadap Kualitas Audit (Studi Pada Kantor Akuntan Publik Surakarta dan Yogyakarta). Skripsi.

Lesmana, R., \& Machdar, N. M. (2015). Pengaruh Profesionalisme, Kompetensi, dan independensi Auditor Terhadap Kualitas Audit. Kalbis Socio : Jurnal Bisnis Dan Komunikasi.

Maharany, Astuti, Y. W., \& Juliardi, D. (2016). Pengaruh Kompetensi, Independensi dan etika Profesi Auditor Terhadap Kualitas Audit ( Studi Empiris Pada KAP di Malang). Malang : Jurnal Akuntansi Aktual.

Mulyadi. (2010). Auditing. Salemba Empat.

Ningsih, S., \& Sofianti, S. P. D. (2015). Pengaruh Kompetensi , Independensi dan Jenis Kelamin Auditor Terhadap Kualitas Audit dengan Kecerdasan Emosional Sebagai Variabel Moderasi : Studi Empiris pada Kantor Akuntan 
Publik di Malang. Artikel Ilmiah Mahasiswa, 1-9.

Oklivia, \& Marlinah, A. (2014). Pengaruh Kompetensi , Independensi dan FaktorFaktor Dalam Diri Auditor Lainnya Terhadap Kualitas Audit. Jurnal Bisnis Dan Akuntansi.

Purwaningsih, P. A. V., \& Suputra, I. D. G. D. (2018). Pengaruh Profesionalisme dan Perilaku Disfungsional Auditor Pada Kualitas Audit dengan Kepuasan Kerja Sebagai Variabel Moderasi. E-Jurnal Akuntansi. https:// doi.org/10.24843/EJA.2018.v24.i01.p09

Sarca, D. N., \& Rasmini, N. K. (2019). Pengaruh Pengalaman Auditor dan Independensi Pada Kualitas Audit Dengan Etika Auditor Sebagai Variabel Moderasi. E-Jurnal Akuntansi, 2240. https://doi.org/10.24843/ eja.2019.v26.i03.p21

Suardinatha, M. H., \& Made Gede Wirakusuma. (2016). Pengaruh Independensi dan Profesionalisme Terhadap Kualitas Audit dengan Kepuasan Kerja Sebagai Variabel Pemoderasi. E-Jurnal Akuntansi Universitas Udayana, 17(3).

Sugiyono. (2018). Metode Penelitian Kuantitatif, Kualitatif, Kombinasi dan RED. CV Alfabeta.

Sukriyah, I., Akram, \& Inapty, B. A. (2009). Pengaruh Pengalaman Kerja, Independensi, Obyektifitas, Integritas dan Kompetensi Terhadap Kualitas Hasil Pemeriksaan Oleh: Pengaruh Pengalaman Kerja, Independensi, Obyektifitas, Integritas Dan Kompetensi Terhadap Kualitas Hasil Pemeriksaan.

Sumito, N., \& Setiyawati, H. (2019). The Influence of Competence, Independence, Professionalism of Internal Auditors and Time Budget Pressure on Audit Quality (Case Study at Inspectorate General of the Ministry of Marine Affairs and Fisheries). Scholars Bulletin. https://doi.org/10.36348/sb.2019.v05i09.002

Susilo, P. A., \& Widyastuti, T. (2015). Integritas, Objektivitas, Profesionalime Auditor dan Kualitas Audit di Kantor Akuntan Publik Jakarta Selatan. Jurnal Riset Akuntansi Dan Perpajakan JRAP. https:/ / doi.org/ISSN 2339-1545

Trisna, M. (2018). Pengaruh Profesionalisme, Integritas, Locus of Control dan Kinerja Auditor pada Kualitas Audit. E-Jurnal Akuntansi Universitas Udayana, 23(3),2061-2089. https://doi.org/https://doi.org/10.24843/EJA.2018.v23.i03.p17

Wulandari, L. G. A. N., \& Made Gede Wirakusuma. (2017). Pengaruh Independensi, Keahlian Audit, Pengalaman dan Besaran Fee Audit Terhadap Kualitas Audit. E-Jurnal Akuntansi, 21(2), 942-969. https://doi.org/10.24843/EJA.2017.v21.i02.p03 